\title{
Links between White Settler Colony in Quebec and the Barriers to the Economic Integration of Skilled Latin American Immigrants
}

\author{
Milagros Calderon Moya \\ McGill University \\ milagros.calderonmoya@mail.mcgill.ca
}

\begin{abstract}
Although Quebec has gone through a period of strong economic growth, it is now struggling with a new labour shortage caused by the shrinking labor pool. Ironically, many foreign-educated immigrants face difficulties associated with entering the labour market and integrating into the workforce. Specifically, recent immigrants from African, Asian, and Latin American countries, who are considered part of visible minority groups, have faced barriers to entry. This paper focuses on the Latin American economic immigrant group and argues that the gap on human and social capital of minority group immigrants and majority group Quebecers cannot be explained simply by analyzing racially motivated actions. Rather, Quebec as a White colonial settler society plays a much more important role in making it very difficult for skilled immigrants to get equal levels of income. By analyzing postcolonial concepts, this document underlines how language politics, notions of citizenship, and global neoliberal capitalism have shaped a harsh labour market that contributes to structural causes for inequality among skilled Latin American immigrants in Quebec.
\end{abstract}

\section{Introduction}

This paper links Quebec's labour shortage with the dilemma of Latin American (LA) skilled immigrants who face barriers in finding employment in their professions, which implies the lack of integration in this society. This paper argues that the gap in immigration literature between human and social capital of minority group immigrants and majority group Quebecers cannot be explained simply by analyzing the rationale of racially motivated individual decision makers as involved stakeholders. Discrimination and racism are clear indicators of Quebec as a White settler society and thus play an important role in the inability of highly skilled immigrants from minority ethnic groups to get equal levels of income. Indeed, such discrepancies are grounded in Quebec's definition of ethno-nationalism that shaped controversial ideas of citizenship that can explain the reasons why government authorities are often inattentive to the structural causes of inequality in Quebec. This article focuses on economic immigrants from the LA group, which, although it is a relatively new and rapidly growing community (Armony, 2014), has received limited scholarly attention in Canada. Specifically, what role does French nationalism play in the misrecognition of the national membership of LA immigrants in Quebec? What is the impact of the provincial government's policy to protect the values of the Quebec national culture by compromising the economic integration of foreign educated professionals from non-White countries of immigration? How can the denial of ongoing processes of economic marginalization and work discrimination contribute to the continuation of systemic or structural discrimination in the province?

Journal of Contemporary Issues in Education, 2021, 16(1), pp. 40-56. 
To be clear, I am not arguing that all French Quebecers are consciously aware, agree, or are oblivious of the White-settler racial order of Quebec. Nevertheless, as ethical members of this society who are aware of systemic discrimination and its consequences, I believe it is our responsibility to question the ongoing and unaddressed marginalization and exclusion of our counterparts. Only then will we be able to begin to understand how patriarchal and capitalist values have favoured the divided and inequalitarian characteristics of our society. I begin with an overview of the Quebec context in order to examine the building of the nation idea in Quebec, as well as the context of the LA presence in the province. I continue with an analysis of postcolonial theory as well as Global Neoliberal Capitalism in order to seek an analysis of the roots of the barriers LA skilled immigrants face in integrating into the Quebec labour market and reach an empirical and normative understanding of the issue. The paper concludes with some recommendations on the consequences of lack of social and economic integration of LA skilled immigrants in the francophone province.

\section{Background to the Study}

Quebec is the only Canadian province where French is the official language, with $79 \%$ of the population who are French speaking (Statistics Canada, 2016). Quebec has an unprecedented authority in selecting its own immigrants as per the 1991 Gagnon Tremblay/McDougall Accord, with a point system that has language skills and provincial labour market needs as priorities (Armony, 2014). In effect, applicants to immigration programs, such as Quebec Experience Program and Quebec Self-Employed Program, are directly chosen by the provincial government, and most of them enter the province under the Quebec Skilled Worker Program (Paquet, 2017). Regarding the main sources of immigration, the origins of Quebec's immigrants differ from those in the rest of Canada (Cousineau \& Boudarbat, 2009). While China, Philippines, and India were the main sending countries for Canada in 2012, in Quebec the top source countries were France, Haiti, and Algeria (Statistics Canada, 2016). Hence, South Asian and Chinese represent the largest "visible minorities" in English Canada while French, Black, Arab and LAs are the most significant minorities in Quebec. It is important to highlight that not all members of ethnic groups are labelled as visible minorities as some of them are phenotypically White.

Due to Quebec's aging population and a declining birthrate, immigrants are critically needed to join the workforce annually and maintain the labour market as a central tool to stimulate the growth of the economy (Serebrin, 2018). In effect, Quebec's current booming economy is now struggling with a new labour shortage in all regions of the province caused by the shrinking labour pool (Shingler \& Rocha, 2017). According to the Fédération canadienne de l'entreprise indépendante, the average labour force growth has gone down from $1.8 \%$ in the 2000 s to $0.7 \%$ for the 2012-2017 period, and thus the growth of the labour force is expected to reach a zero rate and decrease by 2030 (Fillion, 2019). However, the government of Premier François Legault, the political leader of Coalition Avenir Québec (CAQ), a party that identifies itself as nationalist yet holds a position against Quebec sovereignty (Boily, 2018), opted in 2019 to accept fewer skilled immigrants in the coming years. One clear explanation of these lower targets, which are a striking difference to other Canadian provinces, is the fulfillment of the promise CAQ made to citizens against foreigners during the 2018 provincial election campaign. By reducing the 
number of immigrants to Quebec from 50,000 in recent years to approximately 40,000 (between 38,000 and 42,000) annually, Legault's administration uses immigration power as a strategy to better respond to the preferences of Quebec's majority francophone society and its labour market "in the name of" ensuring an adequate integration of new immigrants (El-Assal \& Miekus, 2020). It is important to note, though, that business groups such as the Federation des chambres de commerce du Québec and the Conseil du Patronat du Québec claimed the need to increase the economic immigration to 60,000 people a year in order to reduce the province's labour shortage and stimulate its economy ("Business groups", 2019).

As pointed out by Premier Legault, who leads a majority government, despite their foreign educational credentials, an important number of newcomers are unable to find work in their profession within the first five years of arriving (Valiante, 2019). Yet, the sweeping immigration reform agenda of the party in power disregards entrenched issues of marginalization and discrimination that foreign-educated immigrants face when entering the labour market and integrating into the workforce (Djuikom, 2019). Those individuals are mainly newcomers who are considered part of visible minority groups: immigrants from African, Asian, and LA countries (Haider, 2013). For Lacroix, Gagnon, and Lortie (2017), such unequal treatment is the result of discrimination on the basis of nation and ethnic origin.

It is of importance to account for my positionality as a LA woman and an educator who arrived in Canada as a Quebec-selected skilled immigrant more than 10 years ago and is currently researching the issues related to the economic integration of LA immigrants. I, therefore, acknowledge that my origin, educational background and experiences certainly shape and contribute to my perspectives as a researcher.

\section{The Quebec Scenario}

Although French Canadians were mostly French European descendants and France was also establishing political control in Africa and America, the way in which they were racialized by the colonial and neocolonial Anglo-Saxons deserves particular attention. It should be pointed out that by using the word "race" here, I refer to the way Anglo-Saxon racists employed the term. Despite similarity in skin colour and the presence of the French language in Canada, the colonial history in Quebec resulted in racial discrimination against French colonizers who were considered non-White by the Anglo-Saxon group (Scott, 2016). Examples of this marginalization are the racial discourses found in the Report on the Affairs of British North America published in 1839 where race was used as an argumentative tool to justify the need for the assimilation of French Canadians "in the name of civilization and evolutionary progress" (Scott, 2016, p. 1290). Moreover, the Catholic religion of French Canadians was also used as a marker of difference to legitimize Anglo-Canadian projects. On Scott's account, the satirical magazine called "Punch in Canada" employed a racial rhetoric to sell tales about European racial superiority and depict French colonizers as being of an inferior race and capacity.

As such, the continued social, political, and economic marginalization and exploitation suffered by Québécois was equated to that of Black Americans by the journalist Vallières in his manifesto Nègres blancs d'Amérique (White Niggers of North America). The effect of this controversial 
expression not only resulted in the acknowledgement of an "experience of marginality [and] a sense of collective revolt and injustice" (Scott, 2016, p. 1292) but also reinforced accounts of race and their need for recognition as French Canadians.

However, the transition between being non-White and becoming "White Québécois" was initiated during the awakening of the powerful ethnic and national consciousness, popularly known as the "Quiet Revolution," in the early 1960's (Scott, 2016). The Quebec government challenged English language supremacy by rejecting federal bilingualism (1969) and multiculturalism (1971) policies, and later the Multiculturalism Act (1988) that guaranteed the legal preservation of cultures, languages, and religions of its minorities (Talbani, 1993). For French Quebecers, such forthright objection reinforced their political autonomy from Canada and impeded the cultural extinction of their language and culture. Accordingly, the Quebec government enacted a number of legislative measures to ensure its cultural identity: French became the province's sole official language with Bill 22 in 1974, and the sovereigntist Parti Québécois government adopted the Quebec's Charter of the French Language, also known as Bill 101, in 1977. Bill 101 requires immigrant children to attend French-language schools in order to assimilate newcomers, defending and promoting the role of French language and the cultural identity of the province. In 1983, as a dissent to the federal policy of multiculturalism, which "supports cultural survivalism," the policy of interculturalism was introduced in Quebec to promote the "perspective of assimilation of minority groups" into the Quebec society (Talbani, 1993, p. 412).

Interestingly, the pursuit to build a strong Quebec national identity has resulted in contradictions. The development of the national character of Québécois that placed Quebecers as the dominant ethnic group with access to White privilege (Scott, 2016, p. 1293) occurred while non-French speakers and racialized visible minorities such as Vietnamese, Haitian, and LAs integrated to the province (Ghosh \& Abdi, 2013). Paradoxically, the critical need to increase the Quebec population through immigration resulted in the perception of these cultural groups as a psychological threat to the survival of the French language (Ghosh \& Abdi, 2013) and thus created economic barriers for their integration (Vaillancourt et al., 2007). Indeed, the racial undertone given to the terms "ethnic" and "immigrant" in Quebec has been reflected in those obstacles. A case in point is explained by Ghosh \& Abdi (2013) who underline the discriminatory connotations behind the erroneous assumption that all immigrants are non-White and that all non-White individuals are immigrants. This is observed in the fact that White immigrants integrate more easily to the dominant group in Quebec, while those considered nonWhite are still labeled as immigrants regardless of the time they lived in the province.

This is most clearly demonstrated in the "democratic values and Quebec values test," another fulfilled election promise made by the CAQ, which immigrants to Canada who wish to become permanent residents in Quebec are required to pass since January 2020 (Shingler, 2019). Yet, for immigration lawyers and representatives from ethnic group associations in Quebec, the implications of such tests expose the idea of immigrants as lacking the desired "values" to integrate well into the Quebec society (Lapierre, 2019; Elghawaby, 2019), thus contributing to the "othering" of newcomers. 
According to the Quebec-based research group Institut de recherche et d'informations socioéconomiques (IRIS) (2016), most immigrants to Quebec have higher levels of education than their Canadian-born counterparts. Specifically, IRIS reported that 43\% of Quebec's immigrants are overqualified for their jobs ("Quebec immigrants," 2016). Thus, many immigrants to Quebec decide to settle for precarious and poorly paid employment (Lacroix, 2013), which is associated with negative health effects not only for immigrants but their families (Goldring \& Landolt, 2012), while others decide to leave for provinces offering greater opportunities, such as Ontario and Alberta (Shingler, 2017). The rate of interprovincial migration is obtained by subtracting the number of people leaving the province from the number of people entering it. In the case of Quebec, the total out-migration is much higher than the total in-migration. Indeed, Quebec has shown persistent annual losses in population through interprovincial migration over the past 45 years (Clemens et al., 2016). From 2007 to 2012, around 40,000 residents left through this sort of migration (Mehler, 2012), two-thirds of whom $(15,440)$ were allophones ${ }^{1}$ (Shingler, 2017).

One major area of concern for skilled immigrants, mainly in Quebec, is the non-recognition or devaluation of their foreign educational credentials and experience, which is shown to be a contributing factor to their lower economic prospects in Canada (Armony, 2015b). In consequence, some immigrants from ethnic groups, contrary to those from traditional sources of immigration (Djuikom, 2019), opt to obtain a university or college degree in the host country in order to ensure their employability and professional development in the long term.

However, employers demonstrate biases towards immigrant workers: they tend to prioritize Canadian experience over foreign experience (Dunn, 2016), perceive that immigrant professionals possess insufficient French language proficiency, and may consider having a "strong accent" to be related to someone of lesser skill and competence (Lapointe, 2018). That is to say that the French language plays a key role in Quebec "settler society's ideological project of separating" Whites from non-Whites, the "members" of the nation from ethnic groups, in order to maintain its superiority (Iyengar, 2014, p. 41).

\section{Citizenship in Quebec}

Quebec's Quiet Revolution also led to an active and progressive involvement in the federal approach to immigration law and policy. Indeed, Quebec successfully "pioneer[ed] its way to more provincial power" for decades (Nijboer, 2010, p. 14) and, as mentioned before, was granted autonomy in the selection of its economic immigrants in 1991. Such successful involvement preceded the signature of similar legal agreements with other provincial authorities in order to achieve specific community interests.

Clearly, the various changes in the political, institutional, and social sectors in Quebec that resulted from the legislative measures taken to protect the uniqueness of its cultural identity made a remarkable break with the second-class status Québécois had received for two centuries. With the adoption of French as the language of government and law in 1974, language policy in Quebec built on the existing pillars for structural and institutional racism (Scott, 2016; Haque \&

\footnotetext{
${ }^{1}$ Allophone refers to a resident whose first language is neither French nor English. Journal of Contemporary Issues in Education, 2021, 16(1), pp. 40-56. (c) Author(s), Creative Commons Attribution 4.0 (CC BY 4.0) licence http://ejournals.library.ualberta.ca/index.php/JCIE 
Patrick, 2015) as the new rise of Quebec nationalist sentiment primarily included a notion of race that identified only French Quebecers, who shared a common language, religion, and a set of common ancestors from whom Québécois descended (Makropoulos, 2004). In effect, the new racialized condition of "Québécois" neglected the record of non-French speakers and racialized visible minorities in the French province: it relegated the language of Quebec anglophones and ignored the legitimacy of French-speaking citizens of immigrant origin as equal members of society (Walcott, 2014), such as Chinese individuals who migrated to the province in the late $19^{\text {th }}$ century; it diminished the role of Indigenous peoples as co-founders of Quebec, not to mention their claim as the one and only original founding nation; it ignored the historical struggles of Black people, despite the African-descent presence from the inception of Quebec as a French colony between 1603 and 1608; and it disregarded the historical struggles of other ethnic communities, who provided many essential services (Makropoulos, 2004).

Immigration policy in Quebec clearly favours French-speaking people. Yet, while it has been the main tool through which French has been protected and vitalized since the Quiet Revolution, anti-racist critics agree that Quebec's language politics, which has used the lens of cultural and linguistic differences as the main factor for the province's relations with its internal others, only responded to the province's unavoidable economic need for non-White immigration. Juteau (2002) maintains that language was mainly an instrumental issue for the construction of "the ethnocentric connotations associated with the term Québécois" (p. 448), and, more importantly, was the means through which the Quebec nation built its homogenized notion of citizenship. As such, Quebec institutionalized its strong national identity through the homogenization of the national subject and therefore the assimilation of newcomers since early school age, along with the misrecognition of diverse identities and multiple forms of belongings.

In effect, as the number of non-White immigrant groups in the province greatly increased, Quebec's demographic “characterization of itself" was transformed (Thobani, 2007, p. 144). For Quebecers of French-Canadian descent, the "cultural" differences of immigrants from nonEuropean countries have greatly threatened the nation as a homogenous entity (Thobani, 2007), which certainly reveals the Quebec settler colonial society practices (Haque \& Patrick, 2015; Day, 2016). Moreover, in her study of historical formation and political separation of natives and migrants, Nandita Sharma (2020) argues that citizenship and immigration controls against immigrants are instruments used to secure the Postcolonial New World Order of nation-states which defend their "own racialized, autochthonized ideas of who constitutes the proper "national subject' and, relatedly, each with its own limits to national membership" (Sharma, 2020, p. 201202). Within the terms of this citizenship understanding, the liberalization of citizenship reinforces the authority of those in positions of power and contain threats against the nation as a homogenous entity through the articulation of relations between citizens and minorities as noncitizens (Thobani, 2007). To put it differently, the treatment of minority groups as the ethnic, the perpetual immigrants, or the exogenous of society is a reflection of the racialization and control strategies used over the years "to exclude [people of colour] from Quebec's national story and diminish or negate their social standing” (Austin, 2013, p. 54; Glenn, 2015).

Indeed, the discussion of racism in Quebec is suppressed from public speech; therefore, the onus for racial inequalities experienced by all people of colour is wrongly placed onto their own

Journal of Contemporary Issues in Education, 2021, 16(1), pp. 40-56. 
cultural and linguistic inadequacies to professionally integrate into the local labour market (Haque \& Patrick, 2015). More relevant to my argument is the way citizenship developed as an unattachable concept of cultural belonging. In such context, while majority group members of society continue "to other" members of colour, Quebec's authorities' obliviousness to immigrants' complexities and struggles will continue to play an important role in the socioeconomic boundaries between skilled immigrants from non-White groups and their Quebec-born counterparts.

\section{Latin American Immigrants in Quebec}

Many scholars of immigration, such as Black (2013), Johnston and Komagata (2016), and Knowles (2016), point out that Canadian immigration policies were undoubtedly discriminatory. Indeed, "[t]he institutionalized hierarchy of ethnic preferences" (Potvin, 2010, p. 269) plainly excluded non-White/non-European applicants. An indisputable example of discrimination is the great commotion that the entrance of a group of Black Bermudians, as British colonial subjects, caused in the Nova Scotia Assembly in 1815. The Assembly not only complained to the English Crown for sending this ethnic group to Canada but also requested their repatriation and the further prohibition of such migration (Gutiérrez Rodríguez, 2018). Such Eurocentric bias was related to "Canada's original imaginary as a White settler colony" thus undermining the presence and participation of Aboriginal Nations and immigrants in the nation's history (Galabuzi, 2006, p. 1; Ghosh \& Abdi, 2013).

In like manner, immigration restrictions were based on race, language, and national origin until 1960's. These laws and policies mainly sought individuals from Britain, the United States, and Northern European nations, tolerated those from Southern European nations, but excluded those from other nationalities (Potvin, 2010), such as Middle-Easterners and LAs. However, in 1967, Canada removed national origin as a factor in selecting immigrants and welcomed those from non-European nations "on the basis of educational or occupational qualifications, and of family ties with Canadians and permanent residents in Canada" (Galabuzi, 2006, p. 2). This important reversal in immigration pattern, mainly due to the need for a professional population and global immigration trends, has resulted in Canada's demographic growth dependence on immigration from racialized countries as they represent the main source of the country's labour market (Galabuzi, 2006).

Nevertheless, visible minority individuals have often experienced overt displays of racial discrimination and/or racial microaggressions (Pierce, as cited in Solorzano \& Yosso, 2002). According to a recent study from the Environics Institute for Survey Research, work is the most common place where people of colour face discrimination. Based on this research on people's experiences with racial discrimination at work, Arjumand Siddiqi, the Canada Research Chair in Population Health Equity, casts a critical eye on structural racism and indicates how workplace policies or management systematically oppress some groups compared to others (Bowden, 2019). Concretely, there is a bias at the higher level of organizations to associate certain racial and ethnic groups with certain professions and/or occupations. A specific example would be the fact that for decades, Haitian immigrants have been relegated to do menial labour such as drive taxis in Montreal (Pégram, 2005). 
LA immigration is characterized by social heterogeneity in backgrounds as well as in migration experience (Mata, 1985). Indeed, LA immigration encompasses 20 countries (19 Spanish and a Portuguese speaking one) from North, Central, and South America, including both low-and middle-income countries. Most LA immigrants and their children differ from non-immigrants in ethnic fabric, language, and culture. Historically, immigration from LA to Canada began only six decades ago and has been determined by changes in immigration policy. Indeed, LA immigration to Canada has been shaped by distinct migratory waves. The first migration, called the lead wave, refers to professionals or skilled workers, mainly from Argentina and Brazil and with an ethno-linguistic link to Europe, who arrived in Canada during the 1956-65 period (Mata, 1985). Next was the wave associated with political instability and armed conflicts, also named coup wave (Schugurensky \& Ginieniewicz, 2007), which occurred in the 1970s with the federal's open-door immigration policy. To illustrate, many Chilean and Argentinians refugees arrived in Quebec escaping from dictatorships. Equally important is the Andean wave, mainly composed by Ecuadorians and Colombians, who primarily arrived in Montreal and Toronto during 1973 and 1975 to improve their standards of living (Mata, 1985). Next is the Central American wave of armed conflict in the 1980's, which brought an important number of Salvadorian refugees, who migrated due to political persecution and social losses (Mata, 1985).

In contrast to those migratory groups is the wave of LAs consisting of migrant farm workers to work in peripherical markets that struggle to attract local workers. This wave has gained great importance in the last two decades. Whether hired under the federal Seasonal Agricultural Worker Program (SAWP), which was firstly introduced in 1966 with Caribbean countries (and Mexico and Guatemala years after), or under the agricultural stream of a federal immigration pilot project for low-skilled occupations requiring lower education levels (introduced in 2002), LA temporary farm workers are mainly of Mexican and Guatemalan origin. Importantly, the continuous calls and efforts from various advocacy groups for policy change so that migrant farm workers could unionize and improve their precarious status has not received the required attention from authorities (Paz, 2008). This demand-driven immigration is characterized by lower wages, long shifts of physically demanding labour in the heat, and binding to a single employer for periods of up to eight months (Hanley et al., 2015). Clearly, agricultural workers have received such different treatment from other workers that they are often discouraged to voice their unfair "working conditions or health concerns as this may result in early termination of a contract or eliminate the possibility to return the following year" (Van Haren \& Masferrer, 2019, para.13). By all indications, the origins of such migrant labour recruitment schemes depict a racist ideology that greatly limits legal frameworks from protecting the rights of temporary workers. These schemes therefore result in boundaries between Canadians, in this case Quebecers, and the immigrants who have significantly contributed to maintenance of the agricultural industry (Hanley et al., 2015). Indeed, while agricultural workers play an essential role in the province's food production during the eight months of harvest season, the interest in them as individuals is far from fundamental to authorities and thus to the Quebec society. As Lowe (2007) well recognized: "When migrant workers are constantly positioned as Other, outside of the Canadian identity and imagined community, the Canadian state justifies its policies affecting migrant workers, and the public complies" (Lowe, 2007, p. 18-19). Following this, on Sharma's (2020) account, the state and private capitalist development projects concern 
for immigrants is "simply to ensure an adequate supply of exploitable labor" (Sharma, 2020, p. 166) rather than an equal interest in individuals as contributors to the economic growth.

Lastly, the professional wave of LA migration, which began in the mid-1990s and still continues, includes individuals as independent-class immigrants on the basis of their skills and professional experience (Schugurensky \& Ginieniewicz, 2007). Research indicates that Quebec in particular attracts more LA immigrants under the skilled-worker status than the rest of Canada as a whole (Armony, 2014). While language proximity and Catholic background factors may play an important role for this demographic pull, it does not necessarily translate into positive intergroup relations.

In his study of Quebecers of LA origin in relation to their contradictory welcoming and segregation, Armony (2017) demonstrates that LAs in Quebec are not only distinguished by their trilingualism but by their more frequent use of French at work (69\%) compared to an average of $56 \%$ of all immigrants. Yet, large numbers of LA immigrants face discriminatory practices in the job market and education; such practices have resulted in their social, economic, and political marginalization in Quebec (Armony, 2015a). Statistics from the 2016 census indicate that in Montreal, the most populous city of Quebec, the overall unemployment rate for individuals holding a university degree was $5.7 \%$. Yet, after a further analysis of this rate, the disproportionate unemployment is clearly seen: $10.2 \%$ for visible minorities and $4.3 \%$ for nonvisible minorities, especially Arabs, Blacks, and LAs (Gyulai, 2019, December 25). While these facts are certainly not exclusive to Quebec, the perpetuating low socio-economic status of many professional LA immigrants indicates an undeniable contradiction between the Quebec government's rhetoric on improving strategies to integrate foreign-educated immigrants into the professional labour market and its disregard for the systemic discrimination minority group immigrants face. What follows is an analysis of postcolonial theory and Global Neoliberal Capitalism to examine the links between the Quebec's labour market and the struggles of LA skilled immigrants to find employment in their professional fields.

\section{Postcolonial Theory}

Postcolonial theory largely emerged in the second half of the $20^{\text {th }}$ century, as the structures that ruled colonies such as India (then a British colony) and Algeria (then a French colony) were dismantled. Not surprisingly, its use has extended to explore issues related to "migration, ... difference, [and] race" in order to understand the consequences of prolonged colonial oppression (Ashcroft et al., 1994, p. 2) in places where there is still a colonial dynamic being played out. Yet, the concept of Postcolonialism has been defined in different ways from different perspectives, which may not always agree. What is more, the "post" in the term "postcolonial" was strongly criticized in countries such as Australia and Canada for suggesting that postcolonialism followed decolonization. An example of this is the intergenerational impoverishment and suffering of colonized Indigenous peoples.

Homi Bhabha is one of the most notable postcolonial theorists. Under the context of immigration, Bhabha's idea of mimicry is applied to colonial and postcolonial contexts where dominant societies and/or cultures aim to assimilate minority groups, immigrants included. For 
Bhabha (1994), colonial discourses require subordinates to reproduce dominant culture (values and behaviours), yet those subordinates cannot reach a high similarity that might threaten the colonizer's sense of superiority (Andreotti, 2011). In his reflection on nation, he demonstrates how a postcolonial understanding of difference and otherness is essential to maintain the relations between nation-hood and states (Butt, 2012). He claims that the repetitious conventional narrative of nation, which includes the signification of the peoples, nation, and national identity, is not only reproduced by the state but also by its members. In other words, Bhabha's analysis points out that postcolonial perspectives facilitate the understanding of the forces behind immigration regimes in settler societies as well as of the role that ethnic minority groups subjected to racism, marginalization, oppression, and exploitation play.

More relevant to my analysis is Sharma's conceptualization of the "Postcolonial New World Order" in which she describes how receiving societies (or nation states) apply the Foucauldian concept of governmentality, which refers to the organized rationalities and practices applied to govern, to privilege nationals or natives over migrants (2020). Such new postcolonial global hierarchy is clearly observed when receiving higher salaries and having more workplace rights are inherently reserved to the "nationals or natives" rather than to minority individuals who are not seen as members (Sharma, 2020). It must be noted that in Sharma's conceptualization of membership in a nation, acquiring formal citizenship does not naturally open the gates to a nation as "nationalism is not perfectly expressed through state citizenship laws" (Sharma, 2020, p. 164-165).

In essence, postcolonialism underlines that marginalization is not only an inherent part of the history of Canada and Quebec but also of the large social order that has relegated and relegates its ethnic members, immigrants or not immigrants. Congruent upon this, the links between the normalization of the legally elevated status of Québécois and the legally lower status of minority immigrants are certainly implied by Western discourses of othering (Verkuyten \& Martinovic, 2006). What is more, postcolonial patterns of migration portrayed in the reduction of temporary workers' rights and the barriers to the economic integration of immigrants from racialized groups, like LAs, clearly reflect the ethno-nationalist governmentality of Quebec authorities.

\section{The Global Neoliberal Capitalism}

In the 1990's, the emphasis on global competitiveness created changes in immigration policies in Canada and therefore Quebec. A restructuring of the state economy increased the requirements on the type of independent class immigrants who, by then, not only needed to be highly "skilled and educated and/or wealthy but also 'up and running' on arrival" (Arat-Koc, 1999, p. 31). Neoliberalist structures were adopted to rebuild the economy and, more importantly, shaped and changed the state notions of what citizens could reasonably expect from it (Arat-Koc, 1999).

In more recent times, much of the critical scholarship on settler colonialism indicate it as a contemporary phenomenon in which practices and processes operate within a neoliberal framework (Preston, 2013). To illustrate, the Quebec settler colonialism disguises natural resources extraction projects as ethical economic opportunities for all Canadians and thus "normalise ongoing processes of ... racism, Indigenous oppression and violence" (Preston, 2013, 
p. 43). In this context, Goldberg (2002) points to the racist expression of contemporary states and how they have homogenized racial exclusions to dissipate the normative critique by building an image of racial dispersal. His analysis exposes how racial states have opted to publicly adopt the colour-blind condition as well as the celebration of multiculturalism (interculturalism in the case of Quebec) to legitimate their denial of racially ordered conditions of their "members." This can be seen in the case of the exploitation and abuse temporary agricultural workers suffer in Quebec regions.

In this regard, aiming to achieve equality and merit, critical race theory substantially critiques liberalism, which constructs a wrongful image of a society as fair, egalitarian, and merit-based. More simply, within the neoliberal framework, a society is built on meritocracy so that all of its individual members are seen to have the necessary tools to "compete on a level playing field" (Zamudio et al., 2011, p. 16). Seen from this light, legal protections for minority or vulnerable groups are not a responsibility of society, as it centres the causes of socioeconomic inequality on natural and/or individual causes rather than structural ones. An example of this was the promising and controversial call for Quebec's public consultation on systemic discrimination and racism mandated by former Premier Philippe Couillard, which was announced to take place in the fall of 2017. After strong criticism from his political opponents, the consultations were renamed and changed to a closed-door, one-day forum on immigrant unemployment (Fletcher, 2017). The political argument used for this adjustment was to protect against racial tensions that had increased since the official announcement of the hearing. Yet, opting to invisibilize, and thus normalize, the effects of systemic racism on vulnerable populations is consistent with neoliberal approaches that allege to build a fair, rather than an unequal, society.

Likewise, Premier Legault with the CAQ has constantly sustained his position of the nonexistence of systemic or structural discrimination in Quebec (Banerjee, 2020; Valiante, 2019). Not surprisingly, more than 22,000 Montrealers signed a petition requesting a public consultation on racism and systemic discrimination under the Montreal Charter of Rights and Responsibilities. The consultation was recently held throughout the city and obtained an excellent response from participants, even since its announcement (Gyulai, 2019, October 25). Last June, Anik Pouliot, the spokesperson from the city's Office de la consultation publique, presented the full report to help the municipal administration effectively define clear objectives that could lead to the expected adjustments. To illustrate, a substantial recommendation from the commission is the acknowledgement of the existence of systemic discrimination in order to design and implement the operational changes that specifically address the diagnosis.

Additionally, during the recent legislature committee hearings into Quebec's immigration plan for the next three years, the immigrant and refugee group called Table de concertation des organismes au service des personnes réfugiées et immigrantes (TCRI) heavily criticized the CAQ government's immigration plan, which matches immigrants with open jobs before they arrive in Quebec. For TCRI's representatives, the project opts for the privatization of immigration access and empowers employers to select their own workers, could result in the homogenization of immigrant profiles that would mainly favour European White francophones (Authier, 2019).

Journal of Contemporary Issues in Education, 2021, 16(1), pp. 40-56. 
Certainly, the unwillingness to prioritize adjustments to unequal economic relations expresses an actual protection of the relationships of power over the rights of citizenship of those discriminated. In Thobani's (2007) conceptualization, the intentions behind citizenship are actually to produce significant racial divisions among the populations within the nation-state and achieve national/racial homogeneity regardless of its actual heterogeneity. The Quebec government decides to ignore the continued effects of the racial economic subordination of minority group immigrants, as well as those of temporary workers, by highlighting its theoretical commitment to a neoliberal economic development (Zamudio et al., 2011). For Kuokkanen (2008), not taking immediate political and legal action against structural forms of oppression indicates the patriarchal political values of the national culture that are superimposed over the economic inequality, limited political power, or political exclusion of vulnerable populations as a means of superiority.

Another possible reason for the underutilization of skilled immigrants' human capital is grounded on the logics of White supremacy and neoliberal conditions as the anchor of capitalism (Smith, 2010). Preston (2013) maintains that settler colonialism not only continues to structure the Quebec nation-state but also structures the neoliberal partnerships of private companies and public government to maintain control. In this sense, neoliberal forms in the global economy and labour market deregulation, such as privatization and reductions in government spending to increase the role of the private sector, have greatly impacted minority groups and thus intensified "the persistent historical structures of systemic discrimination" (Galabuzi, 2006, p. 7). This is of special concern because institutions take a passive role by overseeing the obstacles hindering professional integration of minority group immigrants, such as the misrecognition of immigrants' foreign education, as well as the tensions between ethnic groups that may result from this prejudice (Reitz, 2005).

Indeed, the underqualified and low-paid jobs many LA immigrants in Quebec occupy strongly suggest the treatment of their abilities as a cheap commodity and a suitable "supply of exploitable labor" (Sharma, 2020, p. 166) that is always available in the workforce and that helps maintain the capitalist system. Furthermore, Razack (2008) exposes the violence of capitalism in the abstraction of the racial character of labour to create value. In other words, the emphasis of "economic" over "human" attributes of skilled immigrants from minority ethnic groups in Quebec indicate its neoliberal capital notion of individual enterprise in which immigrants are no longer appreciated as a qualified form of human capital but as a form of capital itself. Thus, this objectification and racialization exposes the way a rejected form of capital is neutralized by Whiteness.

\section{Conclusion}

Understanding the double discourses from the Quebec government, which due to its critical need for immigration from racialized countries, selects LA professionals yet prevents them (and other non-White immigrant groups) from economically integrating by disregarding the systemic discrimination against them, is the motivation behind this paper. It is precisely the manner in which historic experiences of exclusion and exploitation of immigrants of colour in Quebec (and Canada) inform patriarchal political values of the Quebec nation that I argue that the ongoing 
presence of a settler colonial society has built the imaginary of a homogenous Quebec citizenship (or cultural belonging) and misrecognizes the long-time heterogeneity of its society. What I mainly draw from critical race theories is the substantial need for maintaining the Quebec ethnonationalism over highly educated immigrants from ethnic minorities, who often see their capabilities constrained even though such commitment deaccelerates the growth of the economy through unmet labor demand, underemployment, or even outmigration. The most compelling evidence is seen through the Quebec ethno-nationalist discourses identified in capitalist immigration policies that normalize and reinforce the marginalization and exclusion of LA temporary farm workers, linguistic and cultural assimilation of immigrant groups, labour market deregulations, political power against consultation on systemic discrimination that endangers individuals who are seen only as commodities, and immigration control strategies that, for instance, measure potential immigrants' ability to blend their resemblance to Quebecers in terms of culture and identity through a values test.

This research has highlighted the critical need for policy makers to turn their focus on the review of strategies for better integrating newcomers to Quebec. To this end, recognizing and attending the roots of racism and discrimination in the Quebec workforce that result in the disproportionate unemployment among minority group immigrants are undoubtedly central for attempting to foster their social and economic integration. This way, marginalized immigrant groups can fully contribute to the enhancement of the local economy, a role for which they were selected. Importantly, such recognition involves dismantling the negative impact of policies that protect the values of the Quebec national culture against the economic prospects of foreign-educated professionals from racialized countries. For this recommendation, consideration needs to be given to the creation of labour programs that address the ethnic gap between professional immigrants from racialized groups and nationals in labour force participation.

\section{Acknowledgments}

I would like to thank my supervisor Dr. Ratna Ghosh for her helpful advice and suggestions. I am also very grateful to Dr. Philip Howard for his feedback on an earlier version of this article.

\section{References}

Andreotti, V. (2011). Actionable postcolonial theory in education. Palgrave Macmillan. El-Assal, K. \& Miekus A. (2020, February 18). Quebec fell even further behind the rest of Canada in attracting immigrants in 2019. CIC News. https://www.cicnews.com/2020/02/quebec-fell-even-further-behind-the-rest-of-canadain-attracting-immigrants-in-2019-0213750.html\#gs.du14qu

Arat-Koc, S. (1999). Neo-liberalism, state restructuring and immigration: Changes in Canadian policies in the 1990s. Journal of Canadian Studies/revue D'études Canadiennes, 34(2), $31-56$.

Armony, V. (2014). Latin American Communities in Canada: Trends in Diversity and Integration. Canadian Ethnic Studies, 46, 3, 7-34.

Armony, V. (2015a). Settling north of the U.S. border: Canada's Latinos and the particular case of Québec. Lasaforum, 46, 4. 
Armony, V. (2015b). Diverging policy approaches to diversity in a bi-national country: The case of Canada. Fédéralisme Régionalisme.

Armony, V. (2017). Les Québécoises et Québécois d'origine latino-américaine: une population bienvenue mais reléguée? Coalition pour l'intégration latino-québécoise.

http://www.midi.gouv.qc.ca/publications/fr/dossiers/valoriserdiversite/memoires/015_MEM_CILQ.pdf

Ashcroft, B., Griffiths, G., \& Tiffin, H. (Eds.). (1994). Post-colonial studies reader. Routledge.

Austin, D. (2013). Nègres blancs, nègres noirs. In Fear of a Black Nation: Race, Sex, and Security in Sixties Montreal (pp. 53-72). Between the Lines.

Authier, P. (2019, August 12). CAQ's immigration plan blasted for favouring European white francophones. Montreal Gazette. https://montrealgazette.com/news/quebec/caqsimmigration-plan-blasted-for-favouring-european-white-francophones

Banerjee, S. (2020). François Legault sticks to position that systemic racism doesn't exist in Quebec. Global News. https://globalnews.ca/news/7042193/francois-legault-sticks-toposition-that-systemic-racism-doesnt-exist-in-quebec/

Bhabha, H.K. (1994). The location of culture. Routledge.

Black, D. (2013, February 15). Canada's immigration history one of discrimination and exclusion. The Star.

https://www.thestar.com/news/immigration/2013/02/15/canadas_immigration_history_on e_of_discrimination_and_exclusion.html

Boily, F. (2018). La coalition avenir québec : une idéologie à la recherche du pouvoir. Les Presses de l'Université Laval.

Bowden, A. (2019, December 11). Racism at work is common - but experts say employers aren't tackling it. Global News. https:/globalnews.ca/news/6279736/racism-inworkplace/?utm_medium=Facebook\&utm_source=GlobalMontreal\&fbclid=IwAR3tw7e _CyICt6SfHOOveuEApoHsesxsVGrrEbqHÜzckP0CivRzBE6BWdL4

Business groups to Quebec gov't: We need more immigrants. (2019, August 12). https://montreal.ctvnews.ca/business-groups-to-quebec-gov-t-we-need-more-immigrants1.4546452

Butt, H. (2012, March 18). A postcolonial perspective on immigration regimes and international order. http://www.e-ir.info/2012/03/18/a-postcolonial-perspective-on-immigrationregimes-and-international-order/

Clemens J., Labrie Y., \& Emes, J. (2016). Interprovincial migration in Canada: Quebeckers vote with their feet. https://www.fraserinstitute.org/studies/interprovincialmigration-incanada-quebeckers-vote-with-their-feet

Cousineau, J. M., \& Boudarbat, B. (2009). La situation économique des immigrants au

Québec. Relations industrielles/Industrial relations, 64(2), 230-249.

https://www.erudit.org/en/journals/ri/1900-v1-n1-ri3404/037919ar.pdf

Day, I (2016) Introduction. In Alien capital: Asian racialization and the logic of settler colonial capitalism (pp. 1-40). Duke University Press.

Djuikom, M.A. (2019). Three essays on the return on investment in human capital of skilled immigrants in Quebec and internal labor migration in developing countries. (Publication No. 34755) [Doctoral dissertation, Université Laval]. https://corpus.ulaval.ca/jspui/bitstream/20.500.11794/33994/1/34755.pdf 
Dunn, T. (2016, November 1). Skilled immigrants struggle to find jobs as government plans to welcome more. $C B C$ News. https:/www.cbc.ca/news/canada/toronto/immigrationemployment-canada-1.3831468

Elghawaby, A. (2019, November 4). Quebec's values test is dangerous politics. The Globe and Mail. https://www.theglobeandmail.com/opinion/article-quebecs-values-test-isdangerouspolitics/?fbclid=IwAR24FCa6OKsUru21QwTOfIRLVNma9OQ2VjSwOW7KsAMjbBd YPjConq_DvM4

Fletcher, R. (2017, October 18). Quebec cancels systemic discrimination consultations. Global News. https://globalnews.ca/news/3811908/quebec-cancels-systemicdiscriminationconsultations/

Fillion, G. (2019, November 05). Immigration : la réforme est-elle dans l'intérêt économique du Québec? [Immigration: is the reform in Québec's economic interest?]. Radio-Canada. https://ici.radio-canada.ca/nouvelle/1376113/economie-immigrants-francois-legault-caqpenurie-travailleursvieillissement?accesVia=partage\&partageApp=appInfoAndroid\&fbclid=IwAR1hgtRyoX 7MQDnJc4Ykds7ZdNjdR3tkiCD5GpkT4YW0Bstx5GDyiQq2dD8

Galabuzi, G.-E. (2006). Canada's economic apartheid: The social exclusion of racialized groups in the new century. Canadian Scholars's Press.

Ghosh, R., \& Abdi, A.A. (2013). Education and the politics of difference: Select Canadian perspectives. Canadian Scholars' Press Inc.

Glenn, E.N. (2015). Settler colonialism as structure: A framework for comparative studies of US race and gender formation. Sociology of Race and Ethnicity, 1(1), 52-72.

Goldberg, D.T. (2002). Introduction: The state of race theory. In The racial state (pp. 1-13). Blackwell.

Goldring, L., \& Landolt, P. (2012). The impact of precarious legal status on immigrants' economic outcomes. IRPP Study, 35, 1.

Gutiérrez Rodríguez, E. (2018). The coloniality of migration and the "refugee crisis": On the asylum-migration nexus, the transatlantic white European settler colonialism-migration and racial capitalism. Refuge: Canada's Journal on Refugees/Refuge: revue canadienne sur les réfugiés, 34(1), 16-28.

Gyulai, L. (2019, October 25). Hearings on racism and systemic discrimination drawing much interest. Montreal Gazette. https://montrealgazette.com/news/local-news/hearings-onracism-and-systemic-discrimination-drawing-much-interest

Gyulai, L. (2019, December 25). Low unemployment rates in Quebec mask systemic discrimination, experts say. Montreal Gazette. https://montrealgazette.com/news/localnews/low-unemployment-rates-in-quebec-mask-systemic-discrimination-experts-say

Haider, M. (2013, May 07). A country of immigrants should know how to integrate them. Huffington Post. http://www.huffingtonpost.ca/murtazahaider/immigrant-unemploymentcanada_b_3541813.html

Hanley, J., Gravel, S., Francisco, V., Daniel, C. V., \& Stephanie, B. (2015). Central American temporary foreign workers in Québec small towns: A portrait of community response. Journal of Rural and Community Development, 10(3), 23-50.

Haque, E. \& Patrick, D. (2015). Indigenous languages and the racial hierarchisation of language policy in Canada. Journal of Multilingual and Multicultural Development, 36(1), 27-41. 
Iyengar, M.M. (2014). Not mere abstractions: Language policies and language ideologies in US settler colonialism. Decolonization: Indigeneity, Education \& Society, 3(2), 33-59.

Johnston, H. (2016). Komagata Maru. The Canadian Encyclopedia. https://www.thecanadianencyclopedia.ca/en/article/komagata-maru

Juteau, D. (2002). The citizen makes an entrée: Redefining the national community in Quebec. Citizenship Studies, 6(4), 441-458.

Knowles, V. (2016). Strangers at our Gates: Canadian immigration and immigration policy, 1540-2015 (4th ed.). Dundurn.

Kuokkanen, R. (2008). Globalization as racialized, sexualized violence: The case of indigenous women. International feminist journal of politics, 10(2), 216-233.

Lacroix, G. (2013). L'intégration en emploi des immigrants de la catégorie des travailleurs qualifiés au Québec, 2002-2009. https://www.mess.gouv.qc.ca/publications/pdf/ADMIN_ETQ_4.pdf

Lacroix, J., Gagnon, A., \& Lortie, V. (2017). At the intersection of gender and national origin: The career trajectories of selected immigrants in Quebec. Population, 72(3), 419-444. https://www.cairn-int.info/article-E_POPU_1703_0435--at-the-intersection-of-genderand-nation.htm

Lapierre M. (2019, October 30). Montrealers react to the Quebec values test. CTV News. https://montreal.ctvnews.ca/montrealers-react-to-the-quebec-values-test-1.4663364

Lapointe, G. (2018). L'immigration péruvienne au Québec: insertion socioéconomique, réseaux sociaux et constructions identitaires. (Publication No. 33837) [Doctoral dissertation, Université Laval]. https://corpus.ulaval.ca/jspui/bitstream/20.500.11794/29947/1/33837.pdf

Lowe, S. J. (2007). Plus ça change?-A comparative analysis of the seasonal agricultural Workers program and the pilot foreign worker program for farm workers in Quebec. [Master's thesis, Ryerson University]. https://digital.library.ryerson.ca/islandora/object/RULA\%3A654

Makropoulos, J. (2004). Speak white! Racism, eh? A critical inter-disciplinary anthology of race and racism in Canada, 242-257.

Mata, F.G. (1985). Latin American immigration to Canada: Some reflections on the immigration statistics. Canadian Journal of Latin American and Caribbean Studies, 10(20), 27-42.

Mehler, A. (2012, December 21). New Canadians love Quebec, but they're leaving it. The Globe and Mail. https://beta.theglobeandmail.com/news/national/new-canadians-love-quebecbut-theyre-leaving-it/article6673482/?ref=http://www.theglobeandmail.com\&

Nijboer, H. (2010). Federal-provincial relations on immigration: Striking the right balance. [Master's thesis, University of Toronto]. https://tspace.library.utoronto.ca/bitstream/1807/25877/3/Nijboer_Harriet_201011_LLM Thesis.pdf

Paquet, M. (2017). Les politiques migratoires. In A.-G. Gagnon \& D. Sanschagrin (Eds.), La Politique Québécoise et Canadienne. Acteurs, Institutions, Sociétés (2nd ed.) (pp. 4-482). Presses de l'Université du Québec.

Paz, A. (2008, June 23). Harvest of injustice: The oppression of migrant workers on Canadian farms. The Bullet. https://socialistproject.ca/2008/06/b117/

Pégram, S. (2005). Choosing their own style: Identity emergence among Haitian youth in Québec. Peter Lang.

Journal of Contemporary Issues in Education, 2021, 16(1), pp. 40-56. 
Potvin, M. (2010). Interethnic relations and racism in Quebec. In J. Rudy, S. Gervais, \& C. Kirkey (Eds.), Quebec questions: Quebec studies for the twenty-first century (pp. 267286). Oxford University Press.

Preston, J. (2013). Neoliberal settler colonialism, Canada and the tar sands. Race \& Class, 55(2), 42-59.

Quebec immigrants more likely to be unemployed, overqualified, report finds. (2016, September 28). $C B C$ News. https://www.cbc.ca/news/canada/montreal/quebec-immigrantsemployment-jobs-1.3781412

Razack, S. (2008). Casting out: The eviction of Muslims from western law and politics. University of Toronto Press.

Reitz, J.G. (2005). Tapping immigrants' skills: New directions for Canadian immigration policy in the knowledge economy. Law \& Business Review of the Americas, 11, 409.

Scott, C. (2016). How French Canadians became white folks, or doing things with race in Quebec. Ethnic and Racial Studies, 39(7), 1280-1297.

Schugurensky, D., \& Ginieniewicz, J. (2007, July 15). The Latin American community in Canada: some challenges ahead. Dialogos. http://dialogos.ca/2007/07/the-latin-americancommunity-in-canada-some-challenges-ahead/

Serebrin, J. (2018, June 13). Aging population is hurting Quebec's economy: PwC study. Montreal Gazette. https://montrealgazette.com/business/aging-population-is-hurtingquebecs-economy-pwc-study

Sharma, N.R. (2020). Home rule: National sovereignty and the separation of natives and migrants. Duke University Press.

Shingler, B. (2017, December 05). Thousands are still leaving Quebec for other provinces. Here's where they're going. $C B C$ News. http://www.cbc.ca/news/canada/montreal/quebec-immigration-provincial-jobs-1.4433749

Shingler, B., \& Rocha, R. (2017, December 05). The downside to Quebec's booming economy? A labour crunch. $C B C$ News. http://www.cbc.ca/news/canada/montreal/quebec-economylabour-1.4431706

Shingler, B. (2019, October 30). Quebec will make immigrants pass 'values' test. CBC News. https://www.cbc.ca/news/canada/montreal/quebec-values-test-immigration-1.5340652

Smith, A. (2010). Indigeneity, settler colonialism, white supremacy. Global Dialogue 12(2), 113.

Solorzano, D. G., \& Yosso, T. J. (2002). A critical race counterstory of race, racism, and affirmative action. Equity \& Excellence in Education, 35(2), 155-68.

Statistics Canada. (2016). Report on the demographic situation in Canada: Permanent and temporary immigration to Canada from 2012 to 2014. https://www.statcan.gc.ca/pub/91209-x/2016001/article/14615-eng.htm

Talbani, A. (1993). Intercultural education and minorities: policy initiatives in Quebec. McGill Journal of Education/Revue des sciences de l'éducation de McGill, 28(003), 407-419.

Thobani, S. (2007). Multiculturalism and the liberalizing nation. In Exalted subjects: Studies in the making of race and nation in Canada (pp. 143-175). University of Toronto Press.

Vaillancourt, F., Lemay, D., \& Vaillancourt, L. (2007). Laggards no more: The changed socioeconomic status of Francophones in Quebec. Backgrounder-CD Howe Institute, (103), 0-1. 
Valiante, G. (2019, August 23). Quebec has accepted 41 per cent fewer skilled workers in first half of 2019, statistics show. The Globe and Mail.

https://www.theglobeandmail.com/canada/article-quebec-has-accepted-41-per-centfewer-skilled-workers-in-first-half-of/

Van Haren, I. \& Masferrer, C. (2019, March 20). Mexican migration to Canada: Temporary worker programs, visa imposition, and NAFTA shape flows. Migration Policy Institute. https://www.migrationpolicy.org/article/mexican-migration-canada

Verkuyten, M., \& Martinovic, B. (2006). Understanding multicultural attitudes: The role of group status, identification, friendships, and justifying ideologies. International Journal of Intercultural Relations, 30(1), 1-18.

Walcott, R. (2014). The book of others (Book IV): Canadian multiculturalism, the state, and its political legacies. Canadian Ethnic Studies, 46(2), 127-13

Zamudio, M., Russell, C., Rios, F., \& Bridgeman, J. L. (2011). Critical race theory matters: Education and ideology. Routledge. 